\title{
Research on the Reform of Enterprise Financial Management Mode under the Background of Big Data
}

\author{
Du Min \\ Zaozhuang University, Zaozhuang, Shandong, China, 277160
}

Keywords: big data; enterprise; finance; management; model; reform

Abstract: With the continuous development of China's Internet technology, China has entered the era of big data. Based on the above background, the paper studies the reform of corporate financial management mode under the background of big data. Firstly, the reform direction of enterprise financial management mode is analyzed under the background of big data, including transforming the functions of financial management personnel, improving the ability of enterprises to obtain information and improving financial information processing capabilities. Secondly, the reform measures of enterprise financial management mode are studied and analyzed under the background of big data. The main measures are increasing financial big data management awareness, adopting step-by-step financial management, building financial big data system and improving financial big data analysis ability.

\section{Introduction}

With the continuous development of China's Internet technology, network information is gradually increasing. China has now entered the era of big data. Big data has the unique characteristics of huge data volume, complex data types, fast data processing speed and high accuracy of data analysis. With the advent of the era of big data, data resources will become the core competitiveness of enterprise competition, which will directly affect the business model and performance level of enterprises. The traditional enterprise financial management model can no longer meet the needs of today's enterprises' production and operation. Therefore, in the context of big data, the financial management model of enterprises should be reformed ${ }^{[1]}$. The reform of enterprise financial management mode is studied and analyzed in this paper, mainly from two aspects. One is the reform direction of enterprise financial management mode under the background of big data. The other is the reform of the corporate financial management model in the context of big data.

\section{The reform direction of enterprise financial management mode under the background of big data}

Nowadays, we are already in the era of big data. Big data has its unique characteristics, including large data content and multiple data types. Big data is mainly based on the development of Internet technology and information technology, and optimizes the efficiency and accuracy of data 
processing. With the advent of the era of big data, the financial management model of enterprises is also undergoing tremendous changes. By applying big data to reform and innovate the financial management model, the financial management of enterprises can adapt to the changes in the era of big data and provide strong support for the development of enterprises ${ }^{[2]}$. The impact of big data on the financial management model is mainly divided into three aspects, as shown in Figure 1.

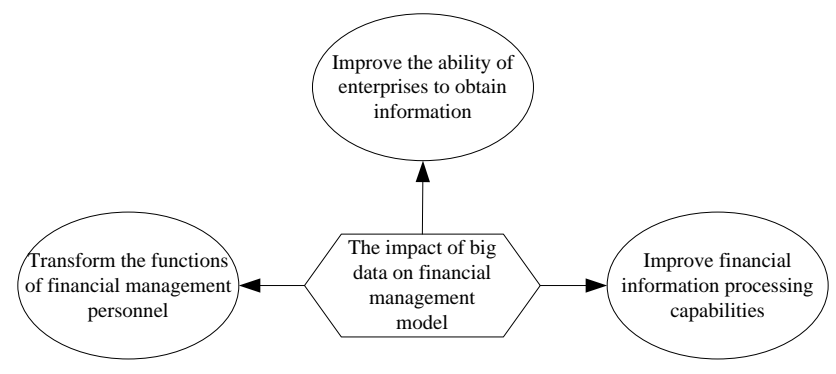

Figure 1 The impact of big data on financial management model

\subsection{Transforming the functions of financial management personnel}

The advent of the era of big data has provided a turning point for the functions of financial management personnel, from the traditional accounting, reporting and other financial management models to the financial management intelligent mode. In the context of big data, higher requirements are placed on financial management personnel, and their level and management level are higher. Especially in the context of comprehensive budget management, big data can not only transform the functions of financial management personnel, but also promote the construction of a comprehensive budget platform for enterprises, which can effectively avoid possible mistakes of financial management personnel. For example, inaccurate data analysis, simple data processing technology, and shallow data analysis. It can organically unify all aspects of financial management, form a complete and effective financial report, and promote the stable development of enterprises ${ }^{[3]}$.

\subsection{Improving the ability of enterprises to obtain information}

As the degree of economic globalization continues to deepen, China's market economy is also constantly developing and changing, and the policy of opening up to the outside world is constantly deepening. The pressure on Chinese enterprises continues to increase, not only facing domestic micro-financial risks, but also facing external macroeconomic pressures. Therefore, only by quickly improving the financial management capabilities of enterprises can we effectively counter risks and pressures. It is necessary to reform the financial management model and innovation cannot be supported by big data technology. Under normal circumstances, enterprises mainly obtain external information data by improving management level and applying information technology. These methods must be based on a strong financial decision-making system, and they have certain limitations. In the context of big data, the financial management model has changed, companies can obtain information data from them, and increase the form and ways to obtain data information. Therefore, enterprises are encouraged to adopt advanced technologies such as information technology and Internet technology to obtain relevant information and data of financial management, which helps to improve the level and quality of financial management.

\subsection{Improving financial information processing capabilities}

The traditional financial management mode mainly deals with financial information through the preparation of data and measurement information. With the continuous improvement of China's 
overall economic level, the financial information of enterprises has gradually increased. The traditional financial management mode seems to be a little powerless in the collection, processing and integration of financial information. It has the defects of inefficiency and high error rate, and the final financial statements cannot support the company to make correct decisions. In the context of big data, the reform of the financial management model, the first thing to pay attention to is the efficiency of financial information processing. It is necessary to form an efficient financial information processing platform within the enterprise to provide effective and reliable data support for enterprise decision-making ${ }^{[4]}$. The use of big data technology enables enterprises to realize a large amount of financial information processing. At the same time, through advanced data information processing technology, the efficiency and precision of processing financial data is greatly improved, and the reform and innovation of enterprise financial management is promoted.

\section{Reform measures of enterprise financial management mode under the background of big data}

Four measures for the reform of the financial management model are proposed in this paper, as shown in Figure 2.

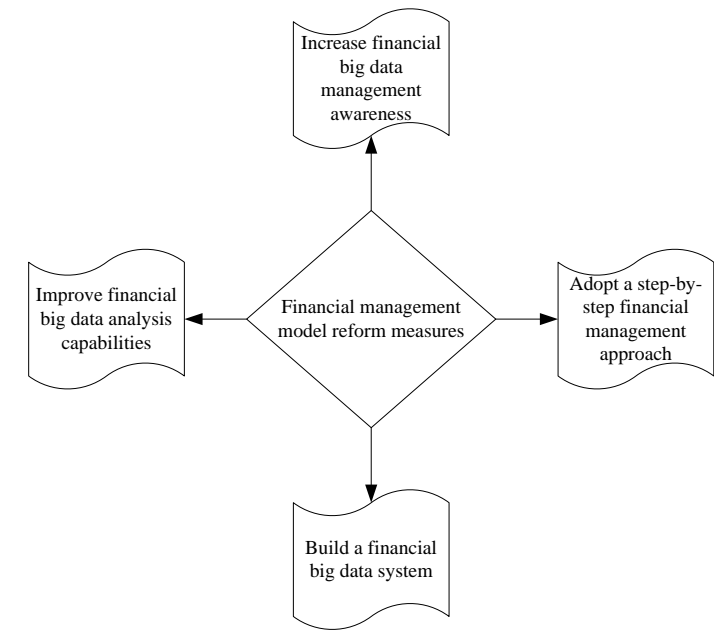

Figure 2 Reform measures for the financial management model

\subsection{Increasing financial big data management awareness}

The financial management personnel of the enterprise do not have a high level of understanding of big data. They do not realize the impact of the advent of the big data era on the financial management model and lack the awareness of financial big data management. Therefore, in order to reform the financial management model, it is necessary to innovate ideas and cultivate the financial big data management awareness of corporate financial management personnel. The main measures to increase the awareness of financial big data management are as follows: First, special training for financial management personnel ${ }^{[5]}$. Teaching financial management personnel's knowledge related to big data, combined with the successful cases of financial big data management, comprehensively improve the financial management personnel's understanding of financial big data management, and strengthen the financial management personnel's awareness of big data management. The second is to organize competitions or questionnaires related to financial big data management, which can deepen the understanding and mastery of financial management personnel on financial big data management. Financial management personnel who are actively involved should be rewarded accordingly, which can effectively enhance the enthusiasm and initiative of financial management 
personnel. The third is to carry out financial big data management work seminars, which can introduce high-level financial management personnel to analyze and study the actual financial big data management of the enterprise. It can not only deepen the understanding of financial management personnel on big data, but also promote the reform of financial management model.

\subsection{Adopting a step-by-step financial management approach}

Nowadays, China is in the stage of exploring big data technology, and there are still many problems in the reform of financial management mode with big data as the background. Therefore, enterprises should establish a big data sharing system to improve the financial management personnel's mastery of enterprise information, and to manage and distribute the enterprise's operational information, and improve the efficiency of corporate financial information processing. Starting from the overall financial management, the financial management of the enterprise is managed in a step-by-step manner ${ }^{[6]}$. Measures to adopt a step-by-step financial management approach: First, speed up the process of financial management informationization, accelerate the standardization of business processes, and build a financial big data analysis system. The second is to find the entry point of big data technology application, and gradually apply big data to a series of business of enterprise financial management, and promote the development of the enterprise based on this. Third, in the process of adopting big data technology, the effect of its use should be continuously monitored and recorded, and the financial management mode of the enterprise should be improved based on this.

\subsection{Build a financial big data system}

In the context of big data, enterprise applications organically combine traditional data development technologies with newly developed technologies to build a financial big data system. Due to the strong scalability of the SOA architecture, the SOA architecture should be chosen in the big data system to establish a service-oriented architecture. In the financial big data system, enterprises can not only integrate information in a centralized manner, but also manage subsystems in a unified manner ${ }^{[7]}$. In addition, in the financial big data system, the subsystems can achieve the functions independently of each other, and can provide diversified services, and reduce the cost of system reorganization through unified interface standards. The financial big data system can implement a variety of functions, including: financial data exchange function; data information processing function; provide financial management program functions.

\subsection{Improving financial big data analysis capabilities}

The ability of enterprise financial data analysis determines the development of the enterprise, including structured, unstructured data analysis, internal data analysis and external data analysis. Financial data analysis can provide data support for enterprise decisions. The data required for enterprise decision-making has multiple and complex characteristics ${ }^{[8]}$. When enterprises obtain decision data, they not only need the internal data information of the financial database, but also their external information. After calculating, analyzing and integrating the financial information, the enterprise establishes contact with other data information of the enterprise to form a corresponding database. The traditional financial management process is inefficient, resulting in a reduction in the overall efficiency of the company. Therefore, the reform of the enterprise financial management model is performed, the first thing is to improve the financial big data analysis capabilities, which can improve the efficiency of financial management, speed up the processing speed and accuracy of financial information, and provide power for the development of enterprises. 


\section{Conclusion}

The advent of the era of big data has not only brought opportunities for corporate financial management, but also brought challenges to it. Enterprises must fully understand the characteristics of the era of big data, and use it as a background to continuously improve and reform the financial management model of the company itself to face the changes of the times. It lays a solid foundation for the good development of enterprises in the era of big data and provides guarantee for the stable development of enterprises. It is hoped that this article will help future research.

\section{References}

[1] Zhang Mimi. Challenges and Changes in Corporate Financial Management under the Background of Big Data [J]. China International Finance (English), 2017, 4(16): 17-17.

[2] Xiao Honglei. Research on the Construction of New Mode of Financial Management Transformation in Power Grid Enterprises in Big Data Era [J]. China Management Information, 2016, 19(10): 29-30.

[3] Wang Lei. Challenge Analysis and Reform of Enterprise Financial Management under the Background of Big Data [J]. Modern Marketing (The Magazine), 2017,6(6):181-181.

[4] Li Yongshan. Challenges and Changes of Enterprise Financial Management Based on Big Data [J]. Accounting Learning, 2017, 79(16):49-50.

[5] Wang Liping. Reform of corporate financial management model based on big data background [J]. MING (Attitude), 2018, 5(13): 5-6.

[6] Fan Yizi. Research on Enterprise Financial Management under the Background of Big Data [J]. Taxation, 2018, 12(13):16-16.

[7] Meng Longhua. A Preliminary Study on the Reform of Enterprise Financial Management Model under Big Data [J]. China Business Trade, 2018, 23(5): 23-24.

[8] Wang Xin, Zhou Xiaomei. Research and Simulation of Big Data Rational Diversion Technology in Cloud Computing Environment [J]. Computer Simulation, 2016, 33(3): 292-295. 